\title{
MONOGRAFIJA „NUO URVINIO ŽMOGAUS IKI ŠIUOLAIKINIO MEGALOPOLIO“
}

Book review

Dalia Bardauskiene

El.paštasdalia.bardauskiene@vgtu.lt

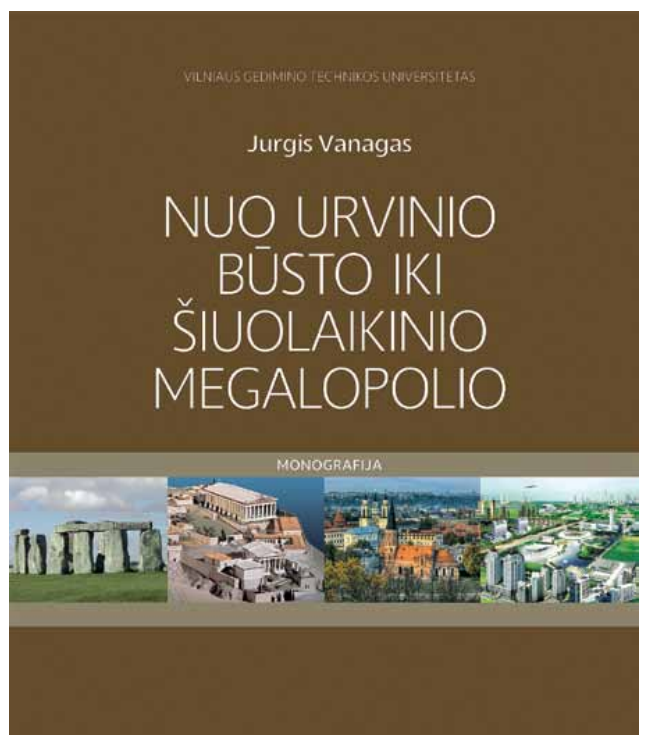

Žymaus Lietuvos mokslininko, pedagogo, urbanistikos tyrejjo ir praktiko prof. habil. dr. Jurgio Vanago monografija „Nuo urvinio žmogaus iki šiuolaikinio megapolio" yra skirta ne tik akademinei bendruomenei, bet ir būsto bei miesto, regioninès plètros specialistams, visuomenei. Monografiją išleido Vilniaus Gedimino technikos universiteto leidykla „Technika“ 2012 metų vasarą.

Monografijos aktualumą įrodo esama urbanistinè situacija. Pasaulio, taip pat ir Lietuvos, žmonija žengia sparčios urbanizacijos keliu, dažnai rizikuodama nutraukti tūkstančius metų pintą íprastinio „stogo virš galvos" tradicijos ir perimamumo giją. Nors ne viskas iš praeities pamirštama, o daug kas atgyja, vis dèlto šiandien dažnai ilgimasi idiliškos senovès auros, vietos dvasios pojūčio, jaukaus žmonių bendravimo. Tai skatina įvairių sričių specialistus siekti sužmoginti miestus, todèl žinios apie būsto ir miesto fenomeną (nuo primityvios pirmykščio žmogaus pastogès, aštria- kuoliais aptvertų sodybų ir piliaviečių iki modernaus, šiuolaikiškai ịrengto namo, iki daugiamilijonių nūdienos urbanistinių darinių - sudètingų aglomeracijų, megapolių) yra labai savalaikès ir svarbios.

Knygos pateikimo skaitytojams metodika - aiški, lakoniška ir profesionali. I tūkstančius metų trukusią žmogaus buveinès raidą autorius žvelgia plačiame kontekste, tačiau svarbiausi faktai nelieka užgožti. Autorius taikliai pastebi svarbiausius architektūros ir urbanistikos, žmonijos ir kultūros raidos faktus, supažindina su iškiliais pasaulinio garso kūrèjais, novatoriais ir reformatoriais, svarbiausiomis pasaulinio garso, urbanizacijos programomis, teorinemis ir praktinemis doktrinomis, ideologiniais motyvais. Perteikdamas skaitytojui daugelị metų kauptas ir visapusiškai subrandintas žinias bei asmenines įžvalgas, autorius tarsi tiki, kad jos padès protingai šeimininkauti ir patenkinti poreikius, užtikrinti nuoseklų miesto ir būsto raidos tęstinumą. Mano, jog žinios apie istorinę raidą padès aiškiau suvokti dabarties reiškinius, leis nekartoti klaidų ir priimti kiek galima racionalesnius sprendimus. Knyga užbaigiama mintimis apie Lietuvos urbanizacijos perspektyvas, suteikiant svarbą Vilniaus ir Kauno dvimiesčiui, kuris atitiktų Europos miesto (Euro City) rango reikalavimus. Simboliškai galima suprasti, kad tai yra autoriaus testamentas Lietuvos urbanistams, priminimas rūpintis projektu, svarbiu krašto gerovei ir urbanizacijos sèkmei.

Monografija pasižymi solidžia apimtimi (191p.), spalvotų iliustracijų gausa ir dideliu literatūros sąrašu bei išskirtinai estetišku knygos apipavidalinimu ir maketu. Knyga kaip papildoma literatūra skirta architektūros, urbanistikos, miestų statybos ir joms artimų specialybių aukštụjų mokyklų studentams. Tačiau, neabejotinai, ji naudinga visiems, kurie dirba gyvenamosios aplinkos kūrimo ir priežiūros srityje, domisi jos raida, perspektyvomis. 